\title{
BMJ Open Chronic health conditions and poverty: a cross-sectional study using a multidimensional poverty measure
}

\author{
Emily J Callander, ${ }^{1}$ Deborah J Schofield, ${ }^{1,2}$ Rupendra N Shrestha ${ }^{1}$
}

To cite: Callander EJ, Schofield DJ, Shrestha RN. Chronic health conditions and poverty: a cross-sectional study using a multidimensional poverty measure. BMJ Open 2013;3: e003397. doi:10.1136/ bmjopen-2013-003397

- Prepublication history for this paper is available online To view these files please visit the journal online (http://dx.doi.org/10.1136/ bmjopen-2013-003397).

Received 13 June 2013 Revised 23 October 2013 Accepted 24 October 2013

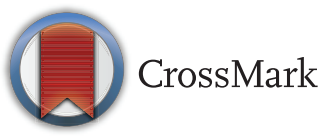

${ }^{1}$ NHMRC Clinical Trials Centre, University of Sydney, Camperdown, New South Wales, Australia

${ }^{2}$ School of Public Health, University of Sydney, Camperdown, New South Wales, Australia

Correspondence to Dr Emily Callander; emily. callander@sydney.edu.au

\section{ABSTRACT \\ Objectives: To identify the chronic health conditions associated with multidimensional poverty. \\ Design: Cross-sectional study of the nationally representative Survey of Disability, Ageing and Carers, conducted by the Australian Bureau of Statistics.}

Setting: Australian population in 2003.

Participants: 35704 individuals randomly selected from the Australian population by the Australian Bureau of Statistics.

Outcome measures: Multidimensional poverty status, costs of disability, short form $6 \mathrm{D}$ health utility score, income, education attainment.

Results: Among those who were multidimensionally poor, $75 \%$ had a chronic health condition and the most common health conditions were back problems ( $11 \%$ of those in multidimensional poverty had back problems) and arthritis (11\%). The conditions with the highest proportion of individuals in multidimensional poverty were depression/mood affecting disorders (26\% in multidimensional poverty) and mental and behavioural disorders (22\%). Those with depression/ mood affecting disorders were nearly seven times ( $O R$ $6.60,95 \% \mathrm{Cl} 5.09$ to $8.55, \mathrm{p}<0.0001$ ) more likely to be multidimensionally poor than those with no health condition. Equivalising for the additional costs of disability increased the proportion of individuals in multidimensional poverty for all conditions and the conditions with the highest proportion of individuals in multidimensional poverty changed.

Conclusions: Owing to the influence of certain health conditions on poverty status, health interventions have the potential to improve national living standards and poverty rates in a similar way that 'traditional' policy responses such as changes to welfare payment currently do. Using a multidimensional poverty measure reveals the health conditions that should be the focus of such efforts.

\section{INTRODUCTION}

Standard of living is a broad concept that loosely relates to the overall life of an individual and the quality of that life. Poverty studies seek to measure an individual's living standards, with those who have a 'poor' standard of living being seen as living in poverty ${ }^{1}{ }^{2}$ Traditionally, poverty has been

\section{Strengths and limitations of this study}

- Uses Australia's first measure of multidimensional poverty.

- Takes into consideration education attainment and overall health status (measured by the Short Form 6D) as well as income when assessing people's poverty status.

- This study contains a sensitivity analysis that takes into consideration the costs of disability when estimating income poverty.

measured based on an individual's available income; however, it is now accepted that income gives too narrow a view of an individual's overall living standards and other indicators of living standards are needed. ${ }^{3}{ }^{4}$ The capabilities theory of Sen has been at the forefront of the movement away from the unidimensional income approach to poverty measurement, with Sen defining poverty as a lack of freedom due to 'the deprivation of basic capabilities'. ${ }^{5}$ Capabilities are resources, attributes or circumstances that give an individual the capacity to adequately function and engage with the society they live in and the ability to do things an individual values. ${ }^{5}$ This shift in conceptualising poverty and living standards has given rise to the nowwidespread use of multidimensional poverty measures. ${ }^{6-10}$ These measures still seek to measure living standards and identify those living in poverty, however they use multiple indicators, not just income.

Overall, health status imparts a massive impact on an individual's living standards by directly influencing what physical and mental functioning they can undertake, and is often seen as a basic capability. ${ }^{5}{ }^{11-14}$ Furthermore, health status affects living standards indirectly through limiting education and financial resources: poor health status may not only reduce the ability to undertake education, ${ }^{15-17}$ but may also limit economic resources through restricting employment. ${ }^{18-21}$ For a 
detailed discussion of how health acts as a key capability and determinant of living standards (see ref. 22).

In recognition of the importance of good health for adequate living standards, health status has been included as a key component in numerous measures of poverty, ${ }^{923-}$ 25 including the Freedom Poverty Measure within Australia. ${ }^{22}$ The Freedom Poverty Measure, a multidimensional measure of poverty, sees overall health status and education attainment as impacting on living standards in a similar way that low income does. ${ }^{22}$ Under the Freedom Poverty Measure, overall health status, in part, determines poverty status: those in multidimensional poverty ${ }^{i}$ have a low income and either poor overall health status or an insufficient level of education attainment.

Including health in a measure of poverty provides the opportunity for cross-portfolio responses to improving the living standards of disadvantaged members of society -with health being seen as a key contributor to low living standards, health interventions have the potential to be a direct policy response to improving living standards alongside existing measures such as reform to social security arrangements. ${ }^{26}$ However, different chronic health conditions are likely to have varying impacts on living standards, with some conditions more severely affecting living standards than others. ${ }^{\text {ii }}$ This paper will look at the relationship between multidimensional poverty, measured using the Freedom Poverty Measure, and specific chronic health conditions in the Australian population to determine which chronic health conditions are associated with multidimensional poverty (being disadvantaged in terms of income AND education or health), and as such their prevention or treatment should be targeted as a cross-portfolio concern.

\section{METHODS}

\section{Data source}

The 2003 Survey of Disability, Ageing and Carers (SDAC) provided the data source for this paper. The SDAC provided detailed self-reported data on sociodemographic status, labour force participation, health and disability status, chronic health conditions and economic information on individuals and their families. ${ }^{\text {iii27 }}$

The 2003 SDAC is a comprehensive, nationally representative survey conducted by the Australian Bureau of Statistics (ABS) between 23 June 2003 and 1 November 2003. ${ }^{28}$ The survey covered individuals in all states and

\footnotetext{
${ }^{\mathrm{i}}$ The use of both income measures of poverty and multidimensional measures of poverty in the literature creates the need to clarify which measure is being used. Hence people may be labelled as being in 'income poverty' or in 'multidimensional poverty' depending on which measure was used-both refer to a state of low-living standards. The term 'freedom poverty' refers to those who are identified as being in multidimensional poverty using the Freedom Poverty Measure.

${ }^{\text {ii } W i t h i n ~ t h i s ~ p a p e r ~ a ~ c h r o n i c ~ h e a l t h ~ c o n d i t i o n ~ r e f e r s ~ t o ~ a ~ s p e c i f i c ~}$ aliment that has lasted, or is likely to last, for six months or more.

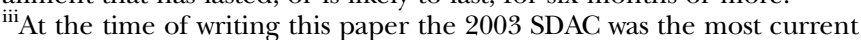
dataset that contains detailed and accurate income, health and education information on the one survey.
}

territories, including rural and urban populationshowever, those in very remote areas were excluded. As these areas make up only $1 \%$ of the population, the ABS deemed that this would not affect the robustness of the data. ${ }^{29}$ Both private dwellings and care-accommodation establishments were included in the sample, with a response rate of $89 \%$ for private dwellings and $92 \%$ for care-accommodation establishments. ${ }^{30}$ Despite the high response rate for the survey, the potential for non-response bias cannot be excluded. It has been noted previously in Australia that people with lower education attainment have been less likely to participate in surveys ${ }^{31}$; hence, this paper may underestimate the number of people in multidimensional poverty. The ABS sought to reduce nonresponse bias through survey design and estimation procedures, ${ }^{30}$ and the use of weighted data in this analysis would also reduce non-response bias, although it cannot be excluded entirely. The original 2003 SDAC data were weighted by the ABS against the 2001 Census of Population and Housing to represent the Australian population in 2003 by broad population variables such as age, sex, state/territory and section of state. ${ }^{27}$

\section{Identifying those in freedom poverty}

In order to determine how various health conditions impact on living standards, the Freedom Poverty Measure was utilised to identify those in multidimensional poverty. The Freedom Poverty Measure combines measures of low income, poor health and insufficient education. The Freedom Poverty Measure was designed specifically for the Australian population in a manner that is consistent with international poverty measurement practices. ${ }^{7}$ For more detailed information on the Freedom Poverty Measure and other examples of its application (see Refs. 101822 and 32).

The income, health and education status of individuals was initially identified as follows:

- If an individual's family income (measured by the income unit income ${ }^{29}$ ) was below $50 \%$ of the median income poverty line, they were considered to have low income.

- If an individual had a poorer health utility score (measured by the Short Form 6D (SF-6D) measure ${ }^{33}$ ) than the average for their age group, they were considered to have poor overall health status.

- If an individual had a highest level of education attainment that was lower than year 12 (for those aged 25-64 years), or lower than year 10 (for those aged 65 years and over), they were considered to have an insufficient level of education attainment.

Those with low income AND either poor overall health status or an insufficient level of education attainment were considered to be in 'freedom poverty' and to be multidimensionally poor.

\section{Identifying chronic health conditions}

The 2003 SDAC recorded any chronic health conditions, defined as health conditions that had lasted or were 
likely to last for 6 months or more, experienced by respondents. If an individual recorded multiple health conditions, their main chronic health condition was also recorded. The ABS classified a respondent's chronic health conditions according to the International Classification of Diseases (ICD)-10 health coding system. Lists of what ICD-10 codes correspond with different chronic health condition groups can be found in ref. 27 Respondents with Alzheimer's disease and 'certain conditions originating in the perinatal period' were excluded because of their low numbers (less than 10 respondents) on the SDAC.

\section{Statistical analysis}

Initially, descriptive statistics were utilised to look at the proportion of people in multidimensional poverty with a long-term health condition, the most common conditions experienced by those in multidimensional poverty and the proportion of people with various conditions in multidimensional poverty.

Following this, logistic regression models were utilised to look at the OR of being in multidimensional poverty for those with various chronic health conditions. Those with no chronic health conditions were used as the reference group, and the models were adjusted for age and sex. Owing to the multiple comparisons being made between different chronic health conditions and no health condition (29 separate models were constructed), there is the potential for type I error to be created. To reduce the risk of this, Bonferroni correction has been undertaken with the significance level set to $0.0017(0.05 / 29)$.

\section{Sensitivity analysis-costs of disability}

Ill health can further impact on living standards by imparting additional costs on individuals, including the costs of treatment, support services and medication, and it has been argued that these costs should be taken into consideration when comparing incomes. ${ }^{34}$ Those with chronic health conditions are likely to need higher incomes to obtain the same level of living standards as those with no chronic health conditions due to the additional costs of living for those with ill health. There is a small amount of literature that has developed a possible means of taking these costs into consideration. Internationally, this has been undertaken by Zaidi and Burchardt, ${ }^{34}$ and within Australia this has been undertaken by Saunders. ${ }^{35}$

Using the methods developed by Saunders to measure the costs associated with disability, a sensitivity analysis was undertaken to look at the difference in the number of people in multidimensional poverty as a result of accounting for the extra costs of disability. The longterm health conditions associated with multidimensional poverty when the additional costs of disability in adults were taken into consideration were also examined. It is acknowledged by the authors that there are a number of limitations to this approach, including the exclusion of children in the methods developed by Saunders and also possible limitations in the use of disability classification to estimate the costs of health. ${ }^{36}$ However, this sensitivity will still provide an example of how taking into consideration the costs of disability will affect the financial situation of individuals and hence the numbers in multidimensional poverty.

\section{RESULTS}

There were 35704 respondents in the SDAC, and of these 3469 were in multidimensional poverty. Once weighted, these data represented 19320000 individuals in the 2003 Australian population in private households, of which 1857000 were multidimensionally poor (10\%). Of the Australian population in 2003, 40\% identified having a long-term health condition.

Not all individuals with a chronic health condition had poor overall health status, with $74 \%$ of individuals with a chronic health condition having good overall health status, indicating that their health condition had only a mild impact on their overall health status. Table 1 shows the overall health status of those with various chronic health conditions. Conditions with a relatively low proportion of individuals reporting poor overall health status included high cholesterol, hypertension and asthma.

Among those who were multidimensionally poor, $75 \%$ were identified as having a chronic health condition. Of those with a chronic health condition, $18 \%$ were in multidimensional poverty, whereas for those with no chronic health condition $4 \%$ were in multidimensional poverty (table 2). Those with a long-term health condition were three times more likely to be in multidimensional poverty than those with no health condition, after controlling for age and sex (OR 3.38, 95\% CI 3.06 to $3.76, \mathrm{p}<0.0001)$.

Among those in multidimensional poverty, the most common health conditions were back problems $(11 \%$ of those in multidimensional poverty had back problems), arthritis and related disorders $(11 \%)$, followed by mental and behavioural disorders $(9 \%)$, hypertension $(4 \%)$, asthma $(4 \%)$ and injury/accident $(4 \%)$. Among the individual health conditions, the conditions with the highest proportion in multidimensional poverty were depression/mood affecting disorders (26\% were in multidimensional poverty), mental and behavioural disorders (22\% were in multidimensional poverty), certain infectious and parasitic diseases $(22 \%$ were in multidimensional poverty) and diseases of the respiratory system (22\% were in multidimensional poverty) (table 3).

After controlling for age and sex, there was no significant difference in the likelihood of being in multidimensional poverty between those with no chronic health condition and those with high cholesterol $(\mathrm{p}=0.3794)$, deafness/noise induced hearing loss $(p=0.3938)$, conditions grouped by the ABS into 'other 2003 codes which had no ICD-10 equivalent' $(\mathrm{p}=0.2993)$, mental and behavioural disorders $(p=0.0441)$, diseases of the blood and blood forming organs $(\mathrm{p}=0.0036)$, diabetes 
Table 1 Overall health status of those with different chronic health conditions

\section{Long-term health condition}

Depression/mood affective disorders

Congenital malformations, deformations and chromosomal abnormalities 49

Symptoms/signs and abnormal clinical and laboratory findings not elsewhere classified

Certain infectious and parasitic diseases

Mental and behavioural disorders

Diseases of the respiratory system

Other injury/poisoning

Injury/accident

Diseases of the blood and blood forming organs

Back problems

Diseases of the skin and subcutaneous tissues

Other diseases of the musculoskeletal system and connective tissue

Arthritis and related disorders

Heart disease

Diseases of the eye and adnexa

Other diseases of the circulatory system

Diabetes

Neoplasms (tumours/cancers)

Diseases of the ear and mastoid process

Diseases of the nervous system $\quad 27$

Diseases of the digestive system 17

Diseases of the genitourinary system 17

Asthma

Hypertension

Other endocrine/nutritional and metabolic disorders

Other

Deafness/hearing loss

High cholesterol

SF-6D, short form 6D.
Proportion with poor overall

health status, measured by SF-6D (\%)

36

41

46

42

40

25

32

28

40

31

33

33

43

12

33 3 17 17 5 $(\mathrm{p}=0.0441)$ and diseases of the genitourinary system (0.0018). Those with depression/mood affecting disorders were nearly seven times (OR 6.60, 95\% CI 5.09 to 8.55, $\mathrm{p}<0.0001)$ more likely to be in multidimensional poverty than those with no chronic health condition. The odds of being in multidimensional poverty for other chronic health conditions, compared to those with no health condition, are shown in table 3.

\section{Costs of disability}

Before equivalising income for disability status, there were 1875000 individuals in multidimensional poverty.

Table 2 Number of individuals in multidimensional poverty by health status, 2003

\begin{tabular}{lll}
\hline & $\begin{array}{l}\text { In } \\
\text { multidimensional } \\
\text { poverty }\end{array}$ & $\begin{array}{l}\text { Not in } \\
\text { multidimensional } \\
\text { poverty }\end{array}$ \\
\hline $\begin{array}{l}\text { Has a long-term } \\
\text { health condition }\end{array}$ & 1387000 & 6371000 \\
$\begin{array}{l}\text { Does not have a } \\
\text { long-term health } \\
\text { condition }\end{array}$ & 449000 & 11113000 \\
\hline
\end{tabular}

After equivalising family income for the costs of disability in adults, there were 2462000 individuals in multidimensional poverty. After equivalising income for the costs of disability in adults, $82 \%$ of people in multidimensional poverty identified with having a chronic health condition -an increase of $8 \%$ points. Of those with a chronic health condition, $27 \%$ were in multidimensional poverty; whereas for those with no chronic health condition $5 \%$ were in multidimensional poverty after equivalising for the costs of disability. Those with a chronic health condition were now more than five times more likely to be in multidimensional poverty than those with no chronic health condition, after controlling for age and sex (OR $5.57,95 \%$ CI 5.07 to $6.12, \mathrm{p}<0.0001)$.

After equivalising for the costs of disability in adults, the most common chronic health conditions among those in multidimensional poverty were still arthritis and related disorders $(13 \%)$, back problems (12\%), mental and behavioural disorders (9\%), hypertension (5\%) and asthma (4\%). The conditions with the highest proportion of individuals in multidimensional poverty were diseases of the respiratory system $(43 \%$ were in multidimensional poverty) and other diseases of the circulatory system ( $41 \%$ were in multidimensional poverty). 
Table 3 Multidimensional poverty status of those with varying long-term health conditions, 2003

\begin{tabular}{|c|c|c|c|c|c|c|c|}
\hline Long-term health condition & $\begin{array}{l}\text { Total } \\
\text { number }\end{array}$ & $\begin{array}{l}\text { Proportion in } \\
\text { multidimensional } \\
\text { poverty (\%) }\end{array}$ & $\begin{array}{l}\text { Number in } \\
\text { multidimensional } \\
\text { poverty }\end{array}$ & OR & \multicolumn{2}{|c|}{$95 \% \mathrm{Cl}$} & p Value \\
\hline No condition & 11562200 & 4 & 488700 & \multicolumn{3}{|c|}{ Reference } & \\
\hline Depression/mood affective disorders & 208400 & 28 & 57300 & 6.60 & 5.09 & 8.55 & $<0.0001$ \\
\hline $\begin{array}{l}\text { Congenital malformations, } \\
\text { deformations and chromosomal } \\
\text { abnormalities }\end{array}$ & 48200 & 17 & 8000 & 5.53 & 3.07 & 9.99 & $<0.0001$ \\
\hline $\begin{array}{l}\text { Symptoms/signs and abnormal } \\
\text { clinical and laboratory findings n.e.c }\end{array}$ & 124700 & 24 & 29500 & 4.71 & 3.29 & 6.76 & $<0.0001$ \\
\hline $\begin{array}{l}\text { Certain infectious and parasitic } \\
\text { diseases }\end{array}$ & 28200 & 24 & 6800 & 4.66 & 2.36 & 9.17 & $<0.0001$ \\
\hline Mental and behavioural disorders & 621800 & 27 & 164900 & 4.60 & 1.04 & 20.35 & 0.0441 \\
\hline Diseases of the respiratory system & 127900 & 27 & 34200 & 4.49 & 3.24 & 6.23 & $<0.0001$ \\
\hline Other injury/poisoning & 65900 & 23 & 14900 & 4.17 & 2.63 & 6.62 & $<0.0001$ \\
\hline Injury/accident & 434700 & 17 & 74900 & 3.85 & 3.11 & 4.77 & $<0.0001$ \\
\hline $\begin{array}{l}\text { Diseases of the blood and blood } \\
\text { forming organs }\end{array}$ & 17200 & 22 & 3700 & 3.72 & 1.53 & 9.00 & 0.0036 \\
\hline Back problems & 1128200 & 19 & 210100 & 3.49 & 3.01 & 4.04 & $<0.0001$ \\
\hline $\begin{array}{l}\text { Diseases of the skin and } \\
\text { subcutaneous tissues }\end{array}$ & 65700 & 15 & 9900 & 3.41 & 2.06 & 5.65 & $<0.0001$ \\
\hline $\begin{array}{l}\text { Other diseases of the } \\
\text { musculoskeletal system and } \\
\text { connective tissue }\end{array}$ & 251600 & 22 & 56300 & 3.35 & 2.59 & 4.33 & $<0.0001$ \\
\hline Arthritis and related disorders & 902200 & 23 & 207200 & 3.27 & 2.79 & 3.83 & $<0.0001$ \\
\hline Heart disease & 225100 & 23 & 52300 & 3.24 & 2.47 & 4.26 & $<0.0001$ \\
\hline Diseases of the eye and adnexa & 99800 & 19 & 19100 & 3.18 & 2.08 & 4.86 & $<0.0001$ \\
\hline $\begin{array}{l}\text { Other diseases of the circulatory } \\
\text { system }\end{array}$ & 122600 & 22 & 27600 & 3.13 & 2.21 & 4.44 & $<0.0001$ \\
\hline Diabetes & 271100 & 19 & 51700 & 2.99 & 2.31 & 3.87 & 0.0441 \\
\hline Neoplasms (tumours/cancers) & 97000 & 19 & 18800 & 2.90 & 1.92 & 4.37 & $<0.0001$ \\
\hline $\begin{array}{l}\text { Diseases of the ear and mastoid } \\
\text { process }\end{array}$ & 284800 & 10 & 47800 & 2.73 & 2.08 & 3.59 & $<0.0001$ \\
\hline Diseases of the nervous system & 491800 & 13 & 65500 & 2.67 & 2.14 & 3.32 & $<0.0001$ \\
\hline Diseases of the digestive system & 154100 & 14 & 21900 & 2.37 & 1.67 & 3.38 & $<0.0001$ \\
\hline $\begin{array}{l}\text { Diseases of the genitourinary } \\
\text { system }\end{array}$ & 70800 & 14 & 9900 & 2.28 & 1.36 & 3.82 & 0.0018 \\
\hline Asthma & 925200 & 8 & 76600 & 2.01 & 1.65 & 2.44 & $<0.0001$ \\
\hline Hypertension & 604200 & 14 & 83200 & 1.84 & 1.50 & 2.26 & $<0.0001$ \\
\hline $\begin{array}{l}\text { Other endocrine/nutritional and } \\
\text { metabolic disorders }\end{array}$ & 87300 & 10 & 8500 & 1.55 & 0.92 & 2.62 & 0.1015 \\
\hline Other & 44700 & 11 & 4812 & 1.48 & 0.71 & 3.10 & 0.2993 \\
\hline Deafness/hearing loss & 153300 & 8 & 12975 & 1.22 & 0.77 & 1.94 & 0.3938 \\
\hline High cholesterol & 92900 & 6 & 5211 & 0.77 & 0.43 & 1.39 & 0.3794 \\
\hline
\end{tabular}

The proportion of individuals in multidimensional poverty in each of these conditions increased after taking into consideration the costs of disability in adults when equivalising income, and the conditions with the highest proportion of individuals in multidimensional poverty also changed (table 4 ).

After controlling for age and sex, those with mental and behavioural disorders were nearly 14 times more likely to be in multidimensional poverty than those with no health condition after equivalising income for disability in adults (OR 13.83, 95\% CI 11.76 to 16.26 , $\mathrm{p}<0.0001)$. All chronic health conditions with the exception of high cholesterol $(p=0.9623)$ were significantly more likely to be in multidimensional poverty than those with no chronic health condition (table 4).

\section{DISCUSSION}

The results have shown that those with a chronic health condition were significantly more likely to be in multidimensional poverty than those without a chronic health condition, with $18 \%$ of those with a chronic health condition being in multidimensional poverty, compared to only $4 \%$ of those without a chronic health condition. Of those in multidimensional poverty, $74 \%$ had a long-term health condition. 
Table 4 Multidimensional poverty status of those with varying long-term health conditions, after equivalising income for the cost of disability in adults, 2003

\begin{tabular}{|c|c|c|c|c|c|c|}
\hline Long-term health condition & $\begin{array}{l}\text { Proportion in } \\
\text { multidimensional } \\
\text { poverty (\%) }\end{array}$ & $\begin{array}{l}\text { Number in } \\
\text { multidimensional } \\
\text { poverty }\end{array}$ & OR & \multicolumn{2}{|c|}{$95 \% \mathrm{Cl}$} & p Value \\
\hline No condition & 4 & 440500 & \multicolumn{3}{|c|}{ Reference } & \\
\hline Mental and behavioural disorders & 36 & 220900 & 13.83 & 11.76 & 16.26 & $<0.0001$ \\
\hline Depression/mood affective disorders & 34 & 71600 & 9.86 & 7.72 & 12.61 & $<0.0001$ \\
\hline $\begin{array}{l}\text { Congenital malformations, deformations and } \\
\text { chromosomal abnormalities }\end{array}$ & 23 & 10900 & 9.82 & 5.70 & 16.92 & $<0.0001$ \\
\hline Certain infectious and parasitic diseases & 38 & 10900 & 9.58 & 5.20 & 17.64 & $<0.0001$ \\
\hline Diseases of the respiratory system & 43 & 55100 & 9.13 & 6.75 & 12.35 & $<0.0001$ \\
\hline Other injury/poisoning & 35 & 23000 & 7.84 & 5.25 & 11.71 & $<0.0001$ \\
\hline Other diseases of the circulatory system & 41 & 49800 & 7.00 & 5.18 & 9.47 & $<0.0001$ \\
\hline $\begin{array}{l}\text { Symptoms/signs and abnormal clinical and } \\
\text { laboratory findings n.e.c }\end{array}$ & 31 & 38400 & 6.97 & 4.93 & 9.85 & $<0.0001$ \\
\hline Diseases of the blood and blood forming organs & 33 & 5700 & 6.94 & 3.40 & 14.17 & $<0.0001$ \\
\hline Diseases of the skin and subcutaneous tissues & 24 & 15700 & 6.69 & 4.35 & 10.30 & $<0.0001$ \\
\hline $\begin{array}{l}\text { Other diseases of the musculoskeletal system } \\
\text { and connective tissue }\end{array}$ & 36 & 91400 & 6.48 & 5.17 & 8.13 & $<0.0001$ \\
\hline Diseases of the eye and adnexa & 31 & 31300 & 6.19 & 4.22 & 9.08 & $<0.0001$ \\
\hline Injury/accident & 23 & 102000 & 6.07 & 5.00 & 7.37 & $<0.0001$ \\
\hline Back problems & 27 & 305400 & 5.80 & 5.08 & 6.63 & $<0.0001$ \\
\hline Arthritis and related disorders & 35 & 316300 & 5.63 & 4.88 & 6.50 & $<0.0001$ \\
\hline Heart Disease & 36 & 80600 & 5.53 & 4.35 & 7.05 & $<0.0001$ \\
\hline Neoplasms (tumours/cancers) & 32 & 31200 & 5.52 & 3.90 & 7.83 & $<0.0001$ \\
\hline Diseases of the nervous system & 20 & 100300 & 4.77 & 3.94 & 5.78 & $<0.0001$ \\
\hline Diabetes & 26 & 70600 & 4.31 & 3.42 & 5.45 & $<0.0001$ \\
\hline Diseases of the ear and mastoid process & 24 & 68500 & 4.23 & 3.32 & 5.39 & $<0.0001$ \\
\hline Other & 26 & 11600 & 4.22 & 2.45 & 7.26 & $<0.0001$ \\
\hline Diseases of the digestive system & 22 & 34400 & 4.14 & 3.07 & 5.60 & $<0.0001$ \\
\hline Diseases of the genitourinary system & 22 & 15400 & 3.92 & 2.52 & 6.09 & $<0.0001$ \\
\hline Asthma & 11 & 104400 & 3.18 & 2.67 & 3.79 & $<0.0001$ \\
\hline Hypertension & 18 & 110000 & 2.42 & 2.01 & 2.92 & $<0.0001$ \\
\hline $\begin{array}{l}\text { Other endocrine/nutritional and metabolic } \\
\text { disorders }\end{array}$ & 13 & 11600 & 2.24 & 1.40 & 3.56 & 0.0007 \\
\hline Deafness/hearing loss & 15 & 22300 & 2.13 & 1.46 & 3.08 & $<0.0001$ \\
\hline High cholesterol & 8 & 7000 & 1.01 & 0.59 & 1.74 & 0.9623 \\
\hline
\end{tabular}

The results of the sensitivity analysis show that after equivalising income for adult disability, there was a 3 percentage point increase in the proportion of the population in multidimensional poverty and a 9 percentage point increase in the proportion of individuals with a chronic health condition in multidimensional poverty. However, there is an opportunity to improve the methods by which the costs of ill health are produced by including children in the methodology and having further consideration as to how health is measured. In spite of this, the sensitivity analysis has shown the additional burden chronic health conditions can have on living standards-through the economic burden placed on families as a result of disability.

Chronic health conditions impact on living standards in a number of ways. Having a chronic health condition results in an increased likelihood of being out of the labour force, ${ }^{19}$ with recent Australian studies showing that being out of the labour force is associated with low incomes and high rates of income poverty. ${ }^{37} 38$
Furthermore, having a chronic health condition is likely to affect an individual's overall health status-however, as this study has shown, different chronic health conditions have varying impacts on overall health status, with some chronic health conditions such as hypertension or asthma having few people reporting poor overall health status.

The chronic health conditions most commonly associated with multidimensional poverty were arthritis and related disorders, back problems and mental and behavioural disorders - all of which have been shown to be preventable. There are numerous interventions for each of these conditions that have been shown to be costeffective in either preventing the onset of the condition or reducing the severity of the condition. ${ }^{39-42}$ When considering the additional costs of low living standards, the further benefits of such intervention programmes become more apparent.

Political rhetoric is currently shifting to advocate the use of cross-portfolio responses to social issues. ${ }^{43}$ As such, there is opportunity for health interventions to be 
taken up in government departments other than those traditionally responsible for healthcare and to be included alongside other efforts to improve living standards such as education and skills reform and social security reform. Using the Freedom Poverty Measure reveals the chronic health conditions that are experienced by the most disadvantaged people in society and should be the focus of political efforts to improve living standards.

Contributors EC conceived, designed and led the study. EC also undertook data analysis and drafted the manuscript. DS and RS provided guidance on data analysis, and contributed to the drafting of the manuscript. All authors edited and approved the final manuscript.

Funding This study was funded partly by a National Health and Medical Research Council (NHMRC) Doctoral Scholarship and an NHMRC Early Career Fellowship.

\section{Competing interests None.}

Ethics approval Ethics approval was obtained from the University of Sydney Human Ethics Committee.

Provenance and peer review Not commissioned; externally peer reviewed.

Data sharing statement The dataset used in this study, the 2003 Survey of Disability, Ageing and Carers, is publicly available for the Australian Bureau of Statistics on application.

Open Access This is an Open Access article distributed in accordance with the Creative Commons Attribution Non Commercial (CC BY-NC 3.0) license, which permits others to distribute, remix, adapt, build upon this work noncommercially, and license their derivative works on different terms, provided the original work is properly cited and the use is non-commercial. See: http:// creativecommons.org/licenses/by-nc/3.0/

\section{REFERENCES}

1. Greenwell H, Lloyd R, Harding A. An introduction to poverty measurement issues. Canberra: National Centre for Social and Economic Modelling (NATSEM). 2001.

2. Townsend P. Poverty in the United Kingdom. Harmondsworth: Penguin, 1979.

3. Travers $\mathrm{P}$, Richardson S. Living decently: material well-being in Australia. Melbourne: Oxford University Press, 1993.

4. Stiglitz J, Sen A, Fitoussi J. Report by the commission on the measurement of economic performance and social progress. Paris: Commission on the Measurement of Economic Performance and Social Progress, 2009.

5. Sen AK. Development as freedom. Oxford: Oxford University Press, 1999.

6. Alkire S, Santos M. A multidimensional approach: poverty measurement \& beyond. Soc Indicators Res 2013;112:239-57.

7. Alkire S, Foster JE. Counting and multidimensional poverty measurement. J Public Econ 2011;95:476-87.

8. United Nations Development Programme. Human Development Report 2008. New York: United Nations Development Programme, 2008

9. United Nations Development Programme. Multidimensional poverty index. New York: United Nations Development Programme; 2010 [cited 21 May 2011]; http://hdr.undp.org/en/statistics/mpi/

10. Callander E, Schofield D, Shrestha R. Multi-dimensional poverty in Australia and the barriers ill health imposes on the employment of the disadvantaged. J Socioeconomics 2011;40:736-42.

11. Council of Australian Governments. Human capital reform. Canberra: Council of Australian Governments, 2006.

12. Council of Australian Governments. Council of Australian Governments Meeting 10 February 2006 Communique. http://www. alga.asn.au/newsroom/communiques/01.coag/COAG Communique 20060210.pdf: COAG2006.

13. Sen AK. Human capital and human capability. World Dev 1997:25:1959-61.

14. Sen AK. Public health ethics and equity. Oxford: Oxford University Press, 2004.

15. Mushkin SJ. Health as an investment. $J$ Political Econ 1962;70:129-57.
16. Laplagne P, Glover M, Shomos A. Effects of health and education on labour force particpation. Canberra: Productivity Commission, 2007.

17. Australian Bureau of Statistics. Australian social trends. Canberra: ABS, 2011.

18. Callander E, Schofield D, Shrestha R. Capacity for freedom-a new way of measuring poverty amongst Australian children. Child Indicators Res 2012;5:179-98.

19. Schofield D, Shrestha R, Passey M, et al. Chronic disease and labour force particpation among older Australians. Med J Aust 2008;189:447-50.

20. Nepal B, Payne A, Brown L. Healthy, wealthy and wise? The relationship between health, employment and earnings in Australia. Sydney: AMP, 2009.

21. Schofield D, Kelly S, Shrestha R, et al. Long term financial impacts of CVD: living standards in retirement. Int J Cardiol 2010;155:406-8.

22. Callander E, Schofield D, Shrestha R. Towards a holistic understanding of poverty: a new multidimensional measure of poverty for Australia. Health Sociol Rev 2012;21:138-52.

23. Lugo MA. Comparing multidimensional indices of inequality: methods and application. Res Econ Inequality 2007;14:213-36.

24. Nilsson T. Measuring Changes in Multidimensional Inequality-an empirical application, 2007.

25. Noble M, Mclennan D, Wilkinson $\mathrm{K}$, et al. The English indices of deprivation 2010. London: Department of Communities and Local Government, 2010.

26. Swan W. Budget Speech 2011-12. Online: http://www.budget.gov. $\mathrm{au} / 2011-12 /$ content/speech $/ \mathrm{html} / \mathrm{speech} . \mathrm{htm}$ : Australian Government; 2011.

27. Australian Bureau of Statistics. Information Paper-Basic Confidentialised Unit Record File: Survey of Disability Ageing and Carers 2003 (reissue). Canberra: ABS, 2004.

28. Australian Bureau of Statistics. Disability ageing and carers Australia: Users guide 4431.0.55.001. Canberra: ABS, 2004

29. Australian Bureau of Statistics. Information Paper-Basic Confidentialised Unit Record File: Survey of Disability Ageing and Carers 2003 (reissue). Canberra: ABS, 2005.

30. Australian Bureau of Statistics. Information Paper-Disability Ageing and Carers Australia: User Guide ABS 4431.0.55.001. Canberra: ABS, 2003.

31. Turrell G, Patterson C, Oldenburg B, et al. The socio-economic patterning of survey participation and non-response error in a multilevel study of food purchasing behaviour: area-and individual-level characteristics. Public Health Nutr 6:181-90.

32. Callander E, Schofield D, Shrestha R. Freedom poverty: a new tool to identify the multiple disadvantages affecting those with CVD. Int $J$ Cardiol 2013;166:321-6.

33. Brazier JE, Roberts J. The estimation of a preference-based measure of health from the SF-12. Med Care 2004;42:851-9.

34. Zaidi A, Burchardt T. Comparing incomes when needs differ: equivalization for the extra costs of disability in the U.K. Rev Income Wealth 2005;51:89-114.

35. Saunders P. The costs of disability and the incidence of poverty. Sydney: Social Policy Research Centre (SPRC). University of New South Wales, 2006

36. Mont D. Measuring Disability Prevalence, SP Discussion Paper. New York: The World Bank, 2007.

37. Schofield D, Shrestha R, Percival R, et al. Economic impacts of illness in older workers: quantifying the impact of illness on income, tax revenue and government spending. BMC Public Health 2011;11:418.

38. Schofield DJ, Callander EJ, Shrestha RN, et al. Premature retirement due to ill health and income poverty: a cross-sectional study of older workers. BMJ Open 2013;3:e002683.

39. Vos T, Carter R, Barendregt JJ, et al. Assessing Cost-Effectiveness in Prevention (ACE Prevention): Final Report. Brisbane and Melbourne: University of Queensland and Deakin University, 2010.

40. Puolakka $\mathrm{K}$, Kautiainen $\mathrm{H}$, Mottonen $\mathrm{T}$, et al. Impact of initial aggressive drug treatment with a combination of disease-modifying antirheumatic drugs on the development of work disability in early rheumatoid arthritis: a five-year randomized follow up trial. Arthritis Rheum 2004;50:55-62.

41. Linton SJ, van Tulder MW. Preventive interventions for back and neck pain problems: what is the evidence? Spine 2001;26:778-87.

42. Barretta B, Byforda S, Knappa M. Evidence of cost-effective treatments for depression: a systematic review. J Affect Disord 2005;84:1-13.

43. Social Inclusion Unit. The Australian Public Service Social Inclusion policy design and delivery toolkit. Canberra: Department of the Prime Minister and Cabinet, editor, 2009. 